\title{
Religion, writing and systematization: reflections on the Annales Maximi
}

\author{
Claudia Beltrão da Rosa[1]
}

\begin{abstract}
The topic of the Annales Maximi has been given special attention by historians until today. Apart from varied interpretations, these books are usually considered under the perspective of the writing of history and Roman memory related issues. This paper addresses the problem of Annales Maximi with respect to Roman religion in an attempt to understand its role in the process of constructing religious knowledge and systematization at the $u r b s$ in the $3^{\text {rd }}$ to $1^{\text {st }}$ centuries BC.
\end{abstract}

Keywords: Annales Maximi; College of Pontiffs; Roman religion.

\section{Religião, escrita e sistematização: reflexões em torno dos Annales Maximi}

\section{Resumo}

O tema dos Annales Maximi ocupou - e ainda ocupa - um lugar especial na atenção dos historiadores, e esses livros, a despeito das variantes interpretativas, são geralmente observados à luz da escrita da história e de questões relativas à memória romana. Este artigo aborda o problema dos Annales Maximi sob o viés dos estudos da religião romana, buscando compreender seu lugar no processo de construção e sistematização do conhecimento religioso na urbs entre os séculos III e I a.C.

Palavras-chave: Annales Maximi; colégio dos pontífices; religião romana.

\section{Religión, escritura y sistematización: reflexiones sobre los Annales Maximi}

\section{Resumen}

El tema Annales Maximi ocupó y - lo continua ocupando - una posición especial para los historiadores, y esos libros a pesar de sus variaciones de interpretación son generalmente observados por la escritura de la historia y de cuestiones referentes a la memoria romana. Esto artigo aborda el problema de los Annales Maximi al bies de los estudios de la religión romana, con el intuito de comprender su posición en el proceso de construcción y sistematización del conocimiento religioso en urbs, entre los siglos III y I a.C.

Palabras clave: Annales Maximi; colegio de los pontífices; religión romana.

\section{La religion, l'écriture et la systematization: réflexions sur les Annales Maximi}

\section{Résumé}

Le thème de l'Annales Maximi a eu une attention particulière des historiens jusquà nos jours et, malgré les diverses interprétations, ces ècrits sont généralement considérés du point de vue de lécriture de l'histoire et de la mémoire romaine. Ce texte examine le problème des Annales Maximi par rapport à la religion romaine, dans le but de comprendre son rôle dans le processus de construction et systématisation de la connaissance religieuse à urbs du IIIe-IIe siècles av- JC.

Mots-clés: Annales Maximi; Collège de Pontifes ; Religion Romaine. 
Pontifices [...] quorum auctoritati fidei, prudentiae maiores nostri sacra religionesque et priuatas et publicas commendarunt

(Cícero. Har. resp. 14).

I n 2009, a seminar entitled Omnium Annalium Monumenta: Annals, Epic and Drama in Republican Rome, was held at the Institutum Romanum Finlandiae (IRF), in Rome. It raised important issues and discussed about the Roman Republic. ${ }^{1}$ One of the main themes, Historical Documentation before Historians: Documentary Evidence and Oral Traditions, brought about the debate on sources traditionally attributed to ancient Roman historians, and the Annales Maximi featured prominently. An event that followed, named Omnium annalium monumenta: Historical Evidence and Historical Writing in Republican Rome, held in 2013, also in Rome, put the spotlights on the topic of the Annales Maximi again. More specifically, issues related to the nature, uses and functions of the commentarii and of the tabulae pontificum were discussed, as well as the fact whether the tabulae were published or not in late Republic under the name of Annales Maximi.

The Annales Maximi, annual records by the pontifex maximus, have had special attention from historians and, despite the wide range of interpretations and controversies, these books are usually considered under the perspective of the writing of history and Roman memory issues. My intention is to look at the Annales Maximi under the light of Roman religion studies. To do so, I will mention ancient references and go through its main "actors" - mostly the Roman College of Pontiffs and particularly the pontifex maximus. Also, I will indicate the guidelines of the debate about the texts, seeking to better understand the role of the pontifical texts in the processes of creation and systematization of the religious knowledge in the $3^{\text {rd }}$ to $1^{\text {st }}$ centuries BC.

\section{Religion, writing and systematization}

In modernity, the questions about sacred books and texts that would codify and store religious postulates and knowledge, and thus establish authorized beliefs, rituals and hierarchies, are central to the studies of religion regarding different human groups. To some experts of our time who are concerned with the dynamics of religious systems, which imply communication of contents, no concept or rule can be communicated without being acquired, codified, stored and passed on by agents who try to preserve them in their basic features. Religious knowledge, codified in language and established in authorized written versions, would therefore be an effective tool for building large scale religious systems that could be spread to groups outside its original locus - surely with regional variations, but without

The seminar was organized by Kaj Sandberg and Christopher Smith, and the interventions were published in 2011 in the Acta Institutum Romanum Finlandiae, Rome. 
losing its main characteristics. ${ }^{2}$ The Roman religious system that can be observed with some certainty in the $2^{\text {nd }}$ and $1^{\text {st }}$ centuries BC was spread through beliefs, practices and rituals forms, reaching places and human groups far away from its original core in Central Italy during the constitution of the Imperium Romanum. One of the central topics for research on Roman religion is the analysis of the means of religious expansion and religious integration in the Imperium. ${ }^{3}$

The modern historiography has searched these sacred books in ancient Rome believing that they would dictate general rules for all worships, and that they had existed since the origins of Rome. Based on projections of current beliefs in the past, some historians also saw Roman religion as an exclusively political phenomenon, and had created and disseminated the idea that there was of a cold and manipulative religion (the "paganism"), ${ }^{4}$ free from actual "religious content". John Scheid argues that "According to this scenario, sacred writing was linked to the birth of ritual; it served to collect, to control and to petrify the natural customs of communication with the divine".

The debates among experts on the nature and organization of the content of these books have always been intense, but the very notion of "sacred writings" is little criticized. Scheid, for instance, talks about the search for these books and collections (monumenta) of libri pontificales, augurales etc. which was carried out in the $19^{\text {th }}$ century AD, starting from postulates such as those declared by Georg Rohde, a modern renowned expert of "pontifical books":

At the beginning of the petrification of ritual, the books were used to fix the cultic rules into memory. This was done in a very laconic way at first, because everybody still knew the features of the cult. But as societies grew more and more complex, the books also became more complex. ${ }^{7}$

\footnotetext{
$\overline{2 H a r v e y ~ W h i t e h o u s e ; ~ R o b e r t ~ N . ~ M c C a u l e y ~(E d s .), ~ M i n d ~ a n d ~ R e l i g i o n: ~ P s y c h o l o g i c a l ~ a n d ~ C o g n i t i v e ~ F o u n d a t i o n s ~}$ of Religiosity, Walnut Creek, Altamira Press, 2005; Harvey Whitehouse; Luther H. Martin (Eds.), Theorizing Religious Past: Archaeology, History, and Cognition, Walnut Creek, Altamira Press, 2004.

${ }^{3} T$ he bibliography on the theme is very extensive, so I will highlight the works by Clifford Ando, "Diana in the Aventine", In: Hubert Cancik; Jörg Rüpke, Die Religion des Imperium Romanum, Tübingen, Mohr Siebeck, 2009, p. 99-113, e The matter of the Gods: Religion and the Roman Empire, Berkeley, University of California Press, 2008; de Andreas Bendlin, "Peripheral centres - Central peripheries: Religious communications in the Roman Empire”, In: Hubert Cancik; Jörg Rüpke, Römische Reichsreligion and Provinzial religion, Tübingen, Mohr Siebeck, 1997, p. 35-65; de Greg Woolf, "World Religion and World Empire in the Ancient Mediterranean", In: Hubert Cancik; Jörg Rüpke, Die Religion des Imperium Romanum, Tübingen, Mohr Siebeck, 2009, p. 1935, and Simon Price, "Religious Mobility in the Roman Empire", Journal of Roman Studies, The Society for the Promotion of Roman Studies, vol. 102, 2012, p. 1-19.

4"Paganism" is a term coined by christian invectives that were succesful in the $19^{\text {th }}$ century. Unduly pejorative, implies the model "Christianity versus Paganism“ in which the former is exalted and the latter not, which leads to the misconception of a religious unity in ancient Rome, revealing not only projective views of current beliefs in the past, as well as the permanence of a christian view of history that has indelibly marked the ways of see and interpret the past.

${ }^{5}$ More on the theme in Claudia Beltrão da Rosa, "A Religião na urbs", In: Gilvan Ventura da Silva; Norma Musco Mendes (Orgs.), Repensando o Império Romano, Rio de Janeiro, EdUFES; Mauad X, 2006, p. 137-159.

${ }^{6} J o h n$ Scheid, "Oral tradition and written tradition in the formation of sacred law in Rome", In: Clifford Ando; Jörg Rüpke (Eds.), Religion and Law in Classical and Christian Rome, Stuttgart, PawB 16, 2006, p. 16.

${ }^{7}$ Georg Rohde apud Idem, Ibidem, p. 17.
} 
In Roman religion, however, if written texts were important, they were just one among other elements that served as tools for religious practices. The Roman religious tradition, strictly speaking, was ever fixed on some literary support that could be considered as a set of christian-like "scriptures", which emanated theological doctrines or policies for religious practice.

It is known that writing already existed in Rome long before the $4^{\text {th }}$ century BC, and some inscriptions point out that written communication had been used in Latium since the $8^{\text {th }}$ century BC, mostly to mark land and object ownership and to record legal and religious regulations. However, a literary culture itself is not available prior to the period traditionally named "Middle Republic". Nowadays, historians agree that from the $3^{\text {rd }}$ century BC on, written texts had become part of the Roman religious arsenal, which gathered hymns, prayers, ritual rules, prescriptions, oracles etc. Anyway, strictly speaking, putting them in the center of the concept of Religion, as "the one" recognized for modern monotheistic religions in the world, is a mistake. ${ }^{8}$

The process through which a religious literary culture began in Rome was part of the general movement that led to the improvement in writing as a means to public communication, especially between members of the Roman elite. The writing - and controlling — of traditions became the path for authority and cause for dispute in aristocratic circles in the $3^{\text {rd }}$ century $\mathrm{BC}$, where they would create and recreate traditions (including mos maiorum ). ${ }^{9}$ According to Thomas Habinek, the audience of the literary performances was not the aristocracy alone, which later on increased and reached a bigger social group through funeral processions and inscriptions, public buildings, visual works etc., overcoming rather than excluding the context of sodalitates. ${ }^{10}$ The literature of the period not only created tradition, but also inserted itself in it. Habinek analyzes the process of institutionalizing literature as a written undertaking that was also professional and restricted to males, considering the means by which it became an aristocratic activity that conveniently placed people in society, including women, according to it:

The transformation in cultural practice that occurred during and immediately following upon the Second Punic War is best regarded not as the invention of literature per se, but as a revolution in the

\footnotetext{
${ }^{8}$ Most of these writings, emanating from many priestly Collegia and disseminated through many materials, have not come to us, and we only have access to a great deal of them through epigraphic excerpts and references in the extensive and varied collection of Latin literature.

9The mos maiorum, a conservative code of moral and behavioral values of Roman aristocrats to which writers such as Cicero frequently refer to support authority, was in fact created in the middle-late Republic literature. According to Habinek, "The mos maiorum is something you know, but also something you do. And one of the things you do in observing the mos maiorum is to participate in the ritualized exhortations, evaluations, and self-criticism that have as their purpose the enforcement of your own adherence to the mos maiorum". Thomas Habinek, The Politics of Latin Literature: Writing, Identity and Empire in Ancient Rome, Princeton, Princeton University Press, 1998, p. 54.

${ }^{10}$ Thomas Habinek, The Politics of Latin Literature: Writing, Identity and Empire in Ancient Rome, Princeton, Princeton University Press, 1998, p. 54. See also Nevio Zorzetti, "The carmina convivalia”, In: Oswin Murray (Ed.), Sympotica: A Symposion on the Symposion. Records of the $1^{\text {st }}$ Symposion on the Greek Symposion, Oxford, Clarendon Press, 1990.
} 
sociology of literary production. Three developments define this revolution: reliance on writing, professionalization of performance, and importation of performers. Whereas archaic literary culture seems to have been characterized by performances that were not necessarily transmitted in writing, the new culture of the late $3^{\text {rd }}$ century and early $2^{\text {nd }}$ centuries B.C.E. was intimately connected with the preservation, importation, and circulation of texts. ${ }^{11}$

The historical change is hard to assess, for it involves many life fields and aspects, where diverse factors interact. Far beyond the raising of a public space in the city of Rome (visible to us), of communication practices and of the religio publica, we are dealing with a huge process of social and cultural change. In a city expanding in every ways, communication and bonds between different groups encouraged the development of institutions, in general, and of religious forms, in particular. The "Middle Republic" saw a process of public systematization and organization while creating and articulating rules for public activities, and developing institutions that could ensure and control the continuity of religious activity, including innovations in practice and institutional creations in the period. The most noteworthy innovations are probably the public priesthoods and their organization into collegia. Some of the main collegia in Late Republic could be identified in the passage of the $4^{\text {th }}$ to the $3^{\text {rd }}$ century BC, and the development of literary culture and the use of writing were an important element of this movement. In the case of religio publica, priesthood records, dramatic performances, epics and historiography helped to systematize religious knowledge, but it was a plural, apparently incoherent, development which demanded specific and group studies.

In short, practices and institutions traditionally attributed to a generic "republican period" were raised and established between the end of the $4^{\text {th }}$ century and during the $2^{\text {nd }}$ century BC: colleges of priests, magistracies, religious rituals, cursus honorum, among others. Therefore, what is usually considered as traditional or ancient by modern historiography could be a relatively recent creation from the $2^{\text {nd }}$ and $1^{\text {st }}$ centuries BC. ${ }^{12}$ In the same vein, what once was believed to be the glimpse of a set of traditional religious practices in the "Middle Republic" could actually be only pertain to some rituals and beliefs of religio domestica and cults, but it could also be much more recent in their origin than we presumed when it comes to religio publica, because:

Roman religion, as we know it is largely the product of the middle and late Republic, the period falling roughly between the victory of Rome over its Latin allies in 338 B.C.E. and the attempt of the Italian people in the Social War to stop Roman domination,

\footnotetext{
"Thomas Habinek, The Politics of Latin Literature: Writing, Identity and Empire in Ancient Rome, Princeton, Princeton University Press, 1998, p. 37.

${ }^{12}$ See Jörg Rüpke, Religion in Republican Rome: Rationalization and Ritual Change, Philadelphia, University of Pennsylvania Press, 2012.
} 
resulting in the victory of Rome over all of Italy in $89 \mathrm{BC}$. Impelled by sea changes in the nature and structure of the Roman aristocracy, and itself helping to consolidate, channel, and constrain those chances, Roman religion was transformed over this period..$^{13}$

The ritualization of collective actions, when they gained stability in a certain space, served as a powerful means of vertical and horizontal social control, establishing what we call religio romana as the result of long social and institutional processes carried out by groups or individuals in specific situations. From the $3^{\text {rd }}$ century $\mathrm{BC}$ on, written texts were added to the ways of religious, political and institutional communication, thus becoming a "tool" to exercise power.

Sticking to the legal and political framework, written language was used long ago to record laws and decisions in the urbs, but protocols or reports appear to have become regular only in the mid- $3^{\text {rd }}$ century BC, especially, with pontifical documents and records of "diplomatic" meetings with representatives of foreign peoples, for which oral communication was predominant earlier. At the time of Cato, written language started to play an important role in internal power struggles. At the end of the $3^{\text {rd }}$ century $\mathrm{BC}$, an interest in systematizing religious knowledge emerged, with special emphasis on the importance of written language in the conduct of rituals and for the control of the calendar of the Republic by the pontiffs. ${ }^{14}$

At the beginning of the $2^{\text {nd }}$ century $\mathrm{BC}$, written language was used by priests, rulers, and state officials (treaties, laws, census, and protocols) and was consolidated in the public space. Priestly texts, like the others, were symbols of power and authority, ${ }^{15}$ and among these, the "pontifical writings" have been given special attention in modern historiography, which tend to see Roman religion as a set of rituals lacking true "religious sense", and only as a political tool aimed at rules and prohibitions. ${ }^{16}$ Current research, however, attempts to go beyond this anachronistic and christianizing vision. This renewal of studies about ancient religions has contributed in reviewing the traditional postulates about Roman religious habits, thus enhancing our understanding about the Roman past.

Based on the above, I will make a few remarks on the College of Pontiffs and the presumed author of the Annales Maximi, the pontifex maximus. Following this, I will cite some references from modern studies in order to provide some key elements to the understanding of the debates surrounding these "books", when it comes to studies of Roman religion.

\footnotetext{
${ }^{13} J$ örg Rüpke, Religion in Republican Rome: Rationalization and Ritual Change, Philadelphia, University of Pennsylvania Press, 2012, p. 1.

${ }^{14} / d e m$, The Roman Calendar from Numa to Constantine: Time, History, and the Fasti, Chichester, Malden-MA, Wiley-Blackwell, 2011 (15t German edition, 1995).

${ }^{15}$ Mary Beard, "Writing and Religion”, In: Sarah I. Johnston (Ed.), Ancient Religions, Cambridge-Mass, Harvard University Press, 2007, p. 127-138; Tim Cornell, "The tyranny of the evidence: a discussion of the possible uses of literacy in Etruria and Latium in the archaic age", In: Mary Beard et al., "Literacy in the Roman World," Journal of Roman Archaeology, Suppl. 3, 1991, p. 7-34.

${ }^{16}$ Claudia Beltrão da Rosa, "A Religião na urbs", In: Gilvan Ventura da Silva; Norma Musco Mendes (Orgs.), Repensando o Império Romano, Rio de Janeiro, EdUFES; Mauad X, 2006, p. 137-159; Also see: C. Robert Philipps III, "Approaching Roman Religion: the case for Wissenschaftsgeschichte", In: Jörg Rüpke, A Companion to Roman Religion, Blackwell: Companions to the Ancient World, Oxford, Blackwell Publishing Ltd., 2007, p. 10-28.
} 


\section{The College of Pontiffs}

The emphasis is placed on the college of pontiffs by modern historiography, whose focus on written documentation remains notable. However, there are no direct records from the college of pontiffs, since we did not have access to original documents. Indirect references and copies of inscriptions with excerpts of pontifical edicts are what we have. Literature provides much information about the college, and these data have been submitted to critical analyses and then compared with other types of documents, resulting in a revived interest in the Roman priestly college by scholars. New issues have been raised in the past years due to concerns other than the basis of traditional approaches to Roman religion as a whole and to pontiffs in particular, from the end of the $19^{\text {th }}$ century until the 1980's.

Some of these ancient texts represent expositions of what the college of pontiffs should be, that is, idealizations. By Varro, with his Antiquitates rerum diuinarum, dedicated to the pontifex maximus Julius Caesar and which came to us in fragments, we have only two excerpts that explicitly refer to

\section{Pontiffs were experts in ius sacrum: investigation \\ of prodigies, pledges, adoptions, heritages, time organization and management}

the college (Ant. diu, 51, 52). It is, however, possible to infer its central role in the work by analyzing the summary by Augustine (Ciu. Dei. VI, 3), and by Cicero, in De republica, 2, which put the pontiffs on the front line of the caerimonia, and the flamines, the salii and the vestals are added, and to the college is given the power of decision over the sacra, which is defined as "religious practices", without specifying if it is about the performance or the supervision of the ceremonies. In De haruspices responso, 14, Cicero adds to the functions of the pontiffs those of the sacra, providing them with public and private competences and mentioning the activities that could be carried out by other people - i.e. magistrates - over whom the pontiffs had some degree of control. He also makes a relevant point in the $\$ 18$ : the pontiffs would have general competence in solemn rituals. The adjective sollemnis here means "annual", which perhaps indicates that what was under the competence of the college were regular ceremonies. ${ }^{17}$ This highlights their control over social time, which is expressed in the cal-

\footnotetext{
${ }^{17}$ Ego uero primum habeo auctores ac magistros religionum calendarum maiores nostros [...] qui statas sollemnisque caerimonias pontificatu, rerum bene gerendarum auctoritates augurio, fatorum ueteris praedictiones Apollinis uatum libris, portentorum expiationes Etruscorum disciplina contineri putauerunt (Har. Resp. 18).
} 
endar. In De natura deorum, I, 122, Cicero suggests again that the sacra are a competence of the pontiffs and describes Roman religion as a division between sacra and auspicia, which is the competence of the augurs, thus adding a third term referring to the predictions of the priests of Sybil: the quimdecemuiri sacris faciundis. ${ }^{18}$ In De legibus, we find a more detailed would it be idealized? - presentation of the duties of the pontiffs based on his philosophical and political ideals. ${ }^{19}$ In the leges de religione, Cicero addresses the organization of the priests and their duties, and also the establishment of the calendar, that is, the annual cycle of festivals (Leg. II, 19-20).

Livy also points out the pontiffs in the Roman public priesthoods, stating that Numa had established the college "so that no part of the divine right would be disturbed by neglecting ancestral rituals or by adopting foreign ones." ( $A b$ urbe condita, I, 20, 5-7 $)^{20}$. In the Res Gestae, written by Augustus, the pontificate, the augurate and the quindecemvirate are mentioned as the first three among the four biggest colleges of priests in the principate $(R G, 7.3)$, followed by the septemuiri epulones. ${ }^{21}$

Pontiffs and augurs are cited in ancient texts as entities dividing competences related to the main fields of Roman religion: the auspicia - created by Romulo, according to tradition (e.g. Cicero, Rep. 2) - and the sacra attributed to Numa (e.g. Cicero. $N D$, III, 5). The former related to signals sent by Jupiter (meaning divine beings/human beings), and the latter to signals sent by human beings to gods. Some pontifical competences can be inferred from the textual evidence when it comes to sacra, such as date, place and victim in public ceremonies, and even competences of experts in all knowledge related to sacra. ${ }^{22}$

Livy goes on stating that the public and private sacra were governed by decrees of the pontiffs, thus conferring on the college decisions of legal force. Among these competencies we highlight the duties of advisors and interpreters, the supervision of religious protagonists such as magistrates and priests, the investigation of prodigies (procuratio prodigiorum), the regulation of uota $^{23}$ and the statement that they were priests of "all gods" (A.u.c. 1, 20).

According to these documents, pontifical decisions were expressed by means that could represent all pontiffs as a whole, that is, their collegiate character. Their decisions and advice were transmitted by the pontifex maximus or a representative. Livy also points out that, until $206 \mathrm{BC}$, the pontifex maximus could

\footnotetext{
${ }^{18}$ The quindecimuiri sacris faciundis were the priests responsible for the Sybiline Books and for the delivery of opinions when establishing new cults and deities in Rome.

${ }^{19}$ Cf. Claudia Beltrão da Rosa, "O uir bonus e a prudentia ciuilis em Marco Túlio Cícero", In: Sônia R. Rebel de Araújo; Claudia Beltrão; Fábio Duarte Joly, Intelectuais, Poder e Política na Roma Antiga, Rio de Janeiro, NAU, 2010, p. 21- 62.

${ }^{20}$ [Numa] Cetera quoque omnia publica priuataque sacra pontificis scitis subiecti [...] ne quid diuini iuris neglegendo patrios ritus peregrinosque adsciscendo turbaretur (I, 20, 5-7).

${ }^{21}$ College composed, after Sulla, by seven priests responsible for the supervision of regular games ( $\left.L u d i\right)$ in Rome.

${ }^{22}$ Mary Beard, "Priesthood in the Roman Republic", In: Mary Beard; John North (Ed.), Pagan Priests: Religion and Power in the Ancient World, London, Duckworth, 1990, p. 17-48, 36-37.

${ }^{23}$ Solemn vows, meaning, in this context, vows by magistrates upon taking over the office.
} 
not leave Italy, for he was considered to be bound to it by the cura sacrorum ( $A$. u. c. $28.38,12 ; 28.44,11$ ), a tradition to be abandoned only in 131 BC (Perioch. $59){ }^{24}$ There are several mentions to funerary rules in inscriptions of pontifical decrees or permissions, which show that the college would also respond to demands by private individuals, even though some inscriptions indicated that some issues that were considered less important were delegated to the kalatores (e.g. CIL VI, 712, 2186, 31034).

Because of their duties as religious experts and actors of the cult, the pontiffs gained prominence, along with other members of the college, as leaders of the sacra, as defined by Cicero. In his theoretical presentations about the pontificate and records of the origins of this priesthood, writers from that time would give more importance to legal activities by these priests when it comes to religion, as against the several categories of interlocutors. Françoise van Haeperen notes that pontifical competencies are usually directed to the restoration and maintenance of pax deorum:

[...] pour son rôle en tant qu'experts et conseillers, les pontifes offertes aux magistrats, au Sénat et aux particuliers les moyens de rétablir de bonnes relations avec les dieux quand ils ont été brisés, ou de prendre des précautions dans les situations où ces relations étaient risqués. ${ }^{25}$

The pontifex maximus appears, in our sources, as the representative of his collegium. He would speak in their name, probably summon his colleagues to and preside at meetings, and also "chose" the vestals, the flaminia and the rex sacrorum $^{26}$. However, pontifical decisions are presented as decrees of the college that should ensure the presence of at least three priests in order to be valid. Yet, the absence of the pontifex maximus would not prevent the college from taking decisions, constituting the Roman principle of tres faciunt collegia (cf. Cicero, De domo sua, 2-3). The pontifex maximus probably had an imminent position on the college and was its representative, unlike other collegia, even the augurs, whose augure maximus did not seem to have the same representation.

In essence, the college of pontiffs had a complex structure, with pontiffs and other priesthoods. As in other priestly collegia, the pontiffs possibly acted in formal meetings and aristocratic banquets, which were an important way of communication. As a general rule, pontiffs were experts in ius sacrum: investigation of prodigies, pledges, adoptions, heritages, time organization and

\footnotetext{
${ }^{24} \mathrm{~A}$ new religious function came up in Principate in the College of Pontiffs-the promagister-which was confirmed by an inscription dated to $155 \mathrm{AC}$ (CIL, VI 2120, ILS 8380, CIL, VI, 32398a) and, previously, the College of Arvales, which would replace the pontifex maximus in Italy in case of his absence. According to John Scheid, "Romulus et ses frères. Le College des Frères Arvales. Modèle de culte public dans la Rome des Empereurs”. BEFAR 275, Paris, De Boccard, 1990, p. 220-228, 242

${ }^{25}$ Françoise van Haeperen, Le Collège Pontifical (3ème s.a.C.-4ème s.p.C.): Contribuition à l'étude de la religion publique romaine, Bruxelles-Rome, Institut Historique Belge de Rome, Brepols Publishers, 2002, p. 429. ${ }^{26}$ See table of composition of the main Roman priestly colleges in Claudia Beltrão da Rosa, "A Religião na urbs", In: Gilvan Ventura da Silva; Norma Musco Mendes (Orgs.), Repensando o Império Romano, Rio de Janeiro, EdUFES; Mauad X, 2006, p. 143
} 
management ${ }^{27}$. The Senate, the magistrates, other priesthoods, the populus and comitia, and even priuati, could request the assistance of the expert priests in the sacra, and in our research sources, the pontiffs appear as advisors in issues related to pax deorum/ira deorum, as the procuratio prodigiorum, the instauratio of ceremonies, matters of lands and properties (divine, human, of Manes), promises, desecration of sacred places, dedications, heritages, adoptions, and the performance of ludi Romani and ludi Plebeii. ${ }^{28}$

Let us return to the priestly records now. Mary Beard, John North and Simon Price refer to these records as a significant portion of traditional duties of priests. On the pontiffs, they comment:

There was a closer connection than we have so far stressed between their interest in family continuity and their practice of record-keeping; and that many of their functions shared a concern with the preservation, from past time to future, of status and rights with families, within gentes and within the Community as a whole - and so also with the transmission of ancestral rites into the future. The pontifices, in short, linked the past with the future by law, remembrance and recording. ${ }^{29}$

Modern historiography has tried to reassemble these records without much success. Among them, the Annales Maximi were considered as the most important because they were supposedly from the pontifex maximus, even though there is no direct evidence of its existence, apart from certain citations and references. It is important to note, therefore, the broad lines of modern discussions about them.

\section{The (modern) problem of Annales Maximi}

The Annales Maximi have been cited by ancient authors, being the most extensive references to them in Cato (Orig. $4=$ Gell. NA2.28.6), Cicero (De Or.2.12.51), Livy (6.1.2; 9.46.5), Servius (Aen.1.373), Macrobius (Sat. 3.2.17),

\footnotetext{
${ }^{27}$ We highlight the participation of the members of the College of Pontiffs in traditional religious parties-the College had an almost exclusive importance in annual parties, except in the Dea Dia, performed by the Arvals, for we have evidence supporting that the Arvals consulted the Pontiffs to perform the ritual, and the Fornicalia, celebrated in February by members of the Curia, who would roast grains. In parties of civil cycle we found a greater variety of participants (other Collegia, magistrates). There are some festivals whose participants are not informed (Terminalia, Equirria), but Pontiffs participated in a number of them (Agonalia, Carmentalia, Virgo parentat, Quirinalia, Regifugium, Argeus, Vestalia, uitutatio, Equus October, Bona Dea, Larentalia, besides the sacrifice of Kalendas, Nonas and Idos). The Pontiffs may have participated along with magistrates in sacrifices of Lavinium Penates, as well as in ceremonies forced by circumstances such as the confarreatio (ancient form of conuentio in manum), diffarreati, assistance to magistrates (for example, at the moment of vows, accompanied by a senatus consultum, the magistrate was assisted by the pontifex maximus, who would dictate him the formula: praeiunte pontifice maximo).

${ }^{28}$ Françoise van Haeperen, Le Collège Pontifical (3ème s.a.C.-4ème s.p.C.): Contribuition à létude de la religion publique romaine, Bruxelles-Rome, Institut Historique Belge de Rome, Brepols Publishers, 2002, p. 215-413.

${ }^{29}$ Mary Beard; John North; Simon Price, Religions of Rome, Vol. 1, Cambridge, Cambridge University Press, 1998, p. 26.
} 
and Aulus Gellius (NA4.5.6). ${ }^{30}$ These passages triggered controversy and discussions in modern times. According to Cicero, for instance, the pontifex maximus compiled the records of the most significant events of the year and filed them in the Regia, his official residence, thus gathering the political, religious and natural events. To Servius, the Annales Maximi were compiled in 80 books.

The Annales Maximi still raise doubts, problems, and even debates concerning their existence. How, when and based on what they were compiled, the authorship, etc. are debated. If they actually existed, what did they address according to ancient authors? Supposedly the oldest mention to the pontifical records in literature is an excerpt in Cato (fr. 77 Peter $=$ A. Gell. NA 2.28.6) in which he compares his works to the tabula of the pontifex maximus, and declares that eclipses and cereal prices were not subjects to be addressed by him. Hence the clue that these were themes addressed in the Annales. About the subject of the tabula, this is the earliest reference assumed. The contents and the method of archiving and conservation of the tabulae are not clear either, since there is no reference, but much modern speculation. Comparing with the priestly commentarii that come to us in inscriptions, ${ }^{31}$ these texts could perhaps include descriptions of the rituals performed every year. Cicero makes Cato regret that there was too much creativity and innovations in records such as the details about the annona. Servius says that the names of magistrates were registered, as well as "domestic and military events on land and at sea" (Aen. 1.373; Gell., NA, 2.28.4).

Modern researchers believe that the Annales Maximi were mainly used as a record of prodigies, a hypothesis supported by the traditional attribution of the procuratio prodigiorum to the college of pontiffs, but there is a lot of controversy

\footnotetext{
30In full: according to the Loeb editions: Cato. Orig. 4 (=Gell. NA 2.28.6): Non lubet scribere, quod in tabula apud pontificem maximum est, quotiens annona cara, quotiens lunae aut solis lumine caligo aut quid obstiterit; Cicero. De Or. 2.12.51: Erat enim historia nihil aliud nisi annalium confectio, cuius rei memoriaeque publicae retinendae causa ab initio rerum Romanorum usque ad P. Mucium pontificem maximum res omnes singulorum annorum mandabat litteris pontifex maximus referebatque in album et proponebat tabulam domi, potestas ut esset populo cognoscendi; ei qui nunc annales maximi nominantur; Livius, 6.1.2: [...] res cum uetustate nimia obscuras, uelut quae magno ex interuallo loci uix cernuntur, tum quod paruae et rarae per eadem tempora litterae fuere, una custodia fidelis memoriae rerum gestarum, et quod, etiam si quae in commentariis pontificum aliisque publicis priuatisque erant monumentis, incensa urbe pleraeque interiere; 9.46.5: [...] ciuile ius, repositum in penetralibus pontificum, euolgavit fastosque circa forum in albo proposuit, ut quando lege agiposset sciretur [...]; Servius. Aen. 1.373: Tabulam dealbatam quotannis pontifex maximus habuit, in qua praescriptis consulum nominibus et aliorum magistratuum digna memoratu notare consueuerat domi militiaeque terra marique gesta per singulos dies, cuius diligentiae annuos commentarios in octoginta libros ueteres rettulerunt eosque a pontificibus maximis, a quibus fiebant, annales maximos appellarunt. Macróbio. Sat. 3.2.17: Pontificibus enim permissa est potestas memoriam rerum gestarum in tabulas conferendi et hos annales appellant equidem maximos quasi a pontificibus maximis factos. Aulus Gellius, NA 4.5.6: Ea historia de aruspicibus ac de uersu isto senario scripta est in Annalibus Maximis, libro undecimo, et in Verri Flacci libro primo Rerum Memoria Dignarum.

${ }^{31}$ The commentarii fratrum arualium and a commentarium by the Ludi Saeculares were some of the rare documents of this type that came to us. Based on them, modern experts created hypotheses about other possible priestly commentarii.
} 
on this. ${ }^{32}$ And Cicero seems to state that Mucius Scaevola, pontifex maximus, decided to terminate the Annales Maximi De (Or.2.52). But why?

In 1971, Elizabeth Rawson raised a number of questions about the Annales Maximi, relating them to the lists of prodigies and to the writing of history in Rome. She also questioned about the public character of these records, arguing that the ancient authors who cited them might not have read the original material:

All we can say with some certainty is that something seemed to prevent both antiquarians as analysts to make use of the Annales Maximi. Maybe they were difficult to use and to have access to them - would be more than one copy? Cicero, in fact, does not talk of them as having been published. ${ }^{33}$

To support her hypothesis, Rawson cites Cicero. The speaker in De Diuinatione states, by the voice of Quintus Cicero, that the best reference for prodigies are texts by historians, for there were no official records before them. ${ }^{34}$ Bruce Frier, on his turn, comments on the lack of evidence for the suppositions by Theodor Mommsen that the tabula was edited in 80 books by Publius Mucius Scaevola, pontifex maximus between 130 and $115 \mathrm{BC}$. He argues that there is no evidence of such edition in texts dating from the Republican period. Based on the hypothesis that the Augustan principate had edited and reviewed ancient records such as the Sibylline books and the Fasti Capitolini, he presumes that the compilation of the Annales Maximi could date from that time..$^{35}$ Frier also defends that the Annales Maximi existed since the beginning of the Republic, which is supported by mentions by historians, especially Livy, A.u.c. I, $20 .{ }^{36} \mathrm{In}$ my view, this interpretation has many weaknesses, including the assumption that the Annales Maximi and the Fasti Capitolini are "ancient records", not creations from the period after the $3^{\text {rd }}$ century BC. Also, there is the lack of evidence for the fact that the Augustan government promoted the aforesaid reviews and editions. ${ }^{37}$ Again, according to Frier's interpretation, the Annales Maximi was

\footnotetext{
${ }^{32} \mathrm{Cf}$. John Scheid, " Les annales des pontifes. Une hypothèse de plus. ", In: Convegno per Santo Mazzarino. Roma, L'Erma di Bretschneider, 1998, p. 199-220; John North, "The books of pontiffs", In: Claudia Moatti (Ed.), La mémoire perdue: recherches sur l'administration romaine. Coll. EFR-A, 243, Paris, École Française de Rome, 1998, p. 65-74; Susanne William Rasmussen, Public Portents in Republican Rome, Roma, L'Erma di Bretschneider, 2003, p. 35-52; Jörg Rüpke, Fasti sacerdotum: A Prosopographic of Pagan, Jewish, and Christian Religious Officials in the City of Rome, 300 BC to AD 499, Oxford, New York, Oxford University Press, 2005, esp. p. 36-38; Ana Rodriguez-Mayorgas, "Annales Maximi: Writing, Memory and Religious Performance in the Roman Republic", In: André P.M.H. Lardinois; Josine H. Blok; Marc G.M. van der Poel (Ed.), Sacred Worlds: Orality, Literacy and Religion, Mnemosyne Suppl., 8, Leiden, Brill, 2011, p. 235-253.

${ }^{33}$ Elizabeth Rawson: "Prodigy lists and the use of the Annales Maximi", Classical Quarterly, vol. 21, 1971, p. 158$69,168-9$

${ }^{34}$ Idem, Ibidem, p. 166.

${ }^{35}$ Bruce Frier, Liber Annales Pontificium Maximorum: The Origins of the Annalist Tradition, Ann Arbor, University of Michigan Press, 1999, p. 193-200.

36/dem, Ibidem, p. 107-119.

${ }^{37}$ Publius Mucius Scaevola, one of the founders of the Roman case law and consul in 133 BC, was one of the nobiles (Frier, op.cit, p. 179-200) that defended a bigger participation of the populus in public businesses (one of the nobiles who supported proposals by Tiberius Gracchus), but there are no elements that explain the alleged discontinuation of the Annales Maximi. According to Frier, the famous pragmatics by Scaevola may have been determinant in making the Annales obsolete in a moment where public records were very effective; Frier raised the hypothesis of an Augustan edition of these texts, but there is no evidence of this.
} 
no longer published in the $1^{\text {st }}$ century $\mathrm{BC}$ and had lost much of their credibility and value as a historical source. ${ }^{38}$

After Rawson and Frier, Robert Drews made extensive comments about ancient references to the Annales Maximi. He says these books were never compiled or published; only the pontifical tabulae existed, but only until the mid$1^{\text {st }}$ century BC. According to the author, the Annales were basically records of prodigies for the procuration and their disappearance is somewhat associated with the decrease in emphasis given to prodigies in the Senate and assemblies. I find this argument questionable. His hypothesis is that the Annales Maximi were compiled by successive pontifices maximi who probably transferred temporary records from the tabula dealbata to papyrus rolls, but left no evidence to support it. ${ }^{39}$ In the $1^{\text {st }}$ century $\mathrm{BC}$, these records would have become obsolete due to an "indifference exhibited by the people regarding prodigies" which would be noticeable since 63 BC. Drews has based his theory on evidence (literary, strongly debatable) that only one prodigy related to Augustus was officially accepted and none related to Tiberius and Caligula. ${ }^{40} \mathrm{He}$ also states about the discontinuation of the practice of keeping the Annales in the pontifex maximus' residence (the domus publica located in the forum romanum) by Mucius Scaevola "was perhaps the first attempt of the ruling class to reduce the public interest for sacrificial rituals. The prohibition of human sacrifice in $97 \mathrm{BC}$ was a safer attempt in the same direction" ${ }^{41}$ Nevertheless, these suppositions are anachronistic and christianizing, with no support for a rigorous analysis of surviving textual and material evidence.

The problematic facts regarding the Annales Maximi were put back on the agenda in the 1990s, when John Scheid published papers on the characteristics and functions of Roman priestly texts, including the Annales Maximi that raised many questions about the pontifical competences related to time control. ${ }^{42}$ First of all, changing the traditional focus of the debate from the writing of history to the analysis of religion and rituals, Scheid stressed the religious character of such texts, and that the Annales Maximi were a summary of important annual events, both positive and negative, for the urbs and it were extracted from the commentarii pontificum. In his view, the Annales Maximi were records of events related to pax or ira deorum, and its main theme was

\footnotetext{
${ }^{38}$ Bruce Frier, Liber Annales Pontificium Maximorum: The Origins of the Annalist Tradition, Ann Arbor, University of Michigan Press, 1999, p. 152. See contra: John Scheid, "Oral tradition and written tradition in the formation of sacred law in Rome", In: Clifford Ando; Jörg Rüpke (Eds.), Religion and Law in Classical and Christian Rome, Stuttgart, PawB 16, 2006, p. 16.

${ }^{39}$ Robert Drews, "Pontiffs, prodigies and the disappearance of the Annales Maximi", Classical Philology, vol. 83, n. 4, 1988, p. 289-299, 296.

40/dem, Ibidem, p. 297.

4l/dem, Ibidem, p. 299.

${ }^{42}$ The three most important articles by John Scheid on the theme, in my view, published in the 1990s, are: "Le temps de la cité et l'histoire des prêtes. Des origines religieuses de la histoire romaine," In: Marcel Detienne (Ed.), Transcrire les mythologies: Tradition, écriture, historicité, Paris, Albin Michel, 1994, p. 149-58; "Les archives de la pieté," In: Segolene Demougin (Ed.), La mémoire perdue: a la recherche des archives oubliées, publiques et privées, de la Rome Antique, Paris, Publications de la Sorbonne, 1994, p. 173-85; e "Les libres Sybillins et les archives des quindécemvirs," In: Claudia Moatti (Ed.), La mémoire perdue: recherches sur l'administration romaine, Coll. EFR-A, 243, Paris, École Française de Rome, 1998, p. 11-26.
} 
the relationships of the urbs with its gods. For him, the fact that these texts were kept in the domus publica, residence of the pontifex maximus, indicate some publicity of them.

Ancient references insist on the supposition that the writing of the tabulae was a competence of the pontifex maximus, but one can only wonder to whom they were directed. Scheid asserts that the Senate and the magistrates must have had an official list of the events of the year. They were to search information related to gods in public proceedings in order to decide the pertinence of fulfillment of vows made in the previous year by new consuls, also to decide the relevance of prodigies. Drawing attention to the "silence of sources" as to the role of pontiffs ${ }^{43}$ in the Senate, Scheid comments:

Il semble difficile d'admettre que les consuls et les sénateurs pourraient, seuls, établir les données nécessaires pour décider sur des promesses ou l'expiation des prodiges. En fait, il ya eu deux débats auxquels ils avaient besoin de conseils pontificaux: au cours de la relatio inaugural, notant que votes précédents aient été remplies et, alors, dans les heures ou les jours suivants, lors de discussions au sujet de les prodiges subsidiaires, qui demandait une procuration. Nous ne pouvions pas croire que la fameuse Chronique du grand pontife serait établi en vue de telles décisions? Le résultat du pouvoir que, selon les sources, le grand pontife devait recevoir les annonces des merveilles, les catastrophes et les succès tout au long de l'année, pourraient viser à établir, à la fin de l'année, un type de rapport pour les consuls et Sénat. ${ }^{44}$

According to this interpretation, the pontifex maximus provided the Senate with a report of relevant public events every year. Under this basis, emanating from a major religious authority, the Senate could take religious decisions, so make the consuls fulfill vows made in the previous year, or in order to a procuratio prodigiorum were carried out. Scheid formulates the hypothesis that the pontiffs acted by virtue of their ius, depending on requests by the Senate. According to him:

Despite what a modern myth would have us believe, there were no priestly or religious books containing a full exposition of doctrine or liturgies. The books of the priestly colleges were reports and records annual celebrations and decisions, as they occurred. They called commentaries. These documents, sometimes old, were a mine of gold for historians and antiquarians, who drew them many information to compose their treatises to which the

\footnotetext{
${ }^{43}$ See Yann Berthelet, who recently defended coherently the presence and importance of the College of Pontiffs in cases of procuratio prodigiorum based on reviews of the famous "anonymous procurations" by Livius in "Le rôle des pontifes dans l'expiation des prodiges à Rome, sous la République: le cas des 'procurations' anonymes", Cahiers Mondes Anciens. Anthropologie et Histoire des Mondes Antiques. $2011-2$. Available at: <http://mondesanciens.revues.org/index348.html>, cited March 3, 2012.

${ }^{44}$ John Scheid, "Les annales des pontifes. Une hypothèse de plus," In: Convegno per Santo Mazzarino. Roma, L'Erma di Bretschneider, 1998, p. 199-220, 218.
} 
contemporaries gave the name libri sacerdotum, pontificum etc., thus contributing to create a myth that had a long life..$^{45}$

More recently, Ana Rodriguez-Mayorgas, ${ }^{46}$ in a rigorous analysis of the remaining documentation, started from the traditional premise that the Annales Maximi did exist and they appeared in the archaic Republic. The author goes through some questions about conservation, transmission and publicizing of the same, based on statements by ancient authors that the pontifex maximus made the tabula available for the public. She questions how "public" this information was, though. Comparing the importance of the supposed public character of these records with the tabulae and the Fasti by Cneus Flavius (304 BC), she questions their content. Following the thesis by Frier, she accepts the declarations by Cicero and Servius that the Annales Maximi were records of important events of the year, mainly on prodigies, bringing summaries, general - not problematic or restricted information, and concludes it is hard to see these texts as a privileged source of information. She, however, emphasizes their importance for the formation of religious memory in the urbs.

The broad framework of this debate tells us that the Annales Maximi were part of the pontifical records, but not the most important one for studies about Roman religion, for they probably brought out records that were also registered by other means. According to Federico Santangelo, the commentarii pontificum are much more relevant for this analysis, for they were not intended for the public. ${ }^{47}$ However, how secret the commentarii pontificum were is very hard to comprehend; there is little evidence and many problems. In a passage of De domo sua, 138, Cicero mentions cases in which pontiffs were consulted about adequate procedures, mentioning that the censor, Gaius Cassius, consulted the college about the dedication of a statue of Concordia and that the praetor, Sextus Julius, consulted them about the dedication of an altar to the vestal Licinia. Cicero explains that these examples were not extracted from pontifical records, but from senatus consulta and magistrate archives including the replies by the pontiffs to requests such as these - therefore, Cicero would speak to the college of pontiffs and claim to know that the commentarii gathered the records of these events, which could ensure guidance for the priests when making decisions (De domo sua, 136). This could be an indication that the commentarii were not in public domain or accessible to members of other relevant

$\overline{45}$ John Scheid, An Introduction to Roman Religion, Bloomington, Indianapolis, Indiana University Press, 2003, p. 111.

${ }^{46}$ Ana Rodriguez-Mayorgas, "Annales Maximi: Writing, Memory and Religious Performance in the Roman Republic," In: André P.M.H. Lardinois; Josine H. Blok; Marc G.M. van der Poel (Ed.), Sacred Worlds: Orality, Literacy and Religion, Mnemosyne Suppl., 8, Leiden, Brill, 2011, p. 235-253.

${ }^{47} F e d e r i c o$ Santangelo, "Pax deorum and Pontiffs," In: James H. Richardson; Federico Santangelo, Priests and State in the Roman World, Stuttgart, Franz Steiner Verlag, 2011, p. 161-186. Cf. também Jersky Linderski, “The Augural Law," ANRW 2.16.3, 1986, p. 2146-2312. 
colleges in res publica such as the augur, Cicero, at least back then, when direct references to the commentarii could be avoided. ${ }^{48}$

Without considering varied and conflicting interpretations, one may infer that the debate on sources of Roman documents was concentrated in priestly records, especially the Annales Maximi. Attention has been given to the organization of the content of such documents, besides the association between Annales Maximi, tabulae pontificum and commentarii. At this point, Jörg Rüpke's contribution is noteworthy because he has done a rigorous analysis and used different types of documents to propose his interpretation.

In Fasti sacerdotum, Rüpke calls the attention to the difficulties concerning the sources about Roman priests, and comments on the commentarii pontificum:

Two important circumstances are related to $249 \mathrm{BC}$, a year that may mark the beginning of the practice of record prodigies in commentarii. The first concerns the Secular Games that year. Very little is known about older conceptions of saeculum, but it is certain that here, with the promise to repeat an event after one hundred years, was introduced in cultic practice a fixed period that, as transcending any conceivable period of human life, needed a careful chronological record and degree of institutionalization. This is not to say that this was the only function that fell to commentarii, but the Secular Games represent a context that makes conceivable the beginning of these records. [...] The second circumstance is related to the Pontifex Maximus of the year $249 \mathrm{BC}$, the first person to whom the initiative of such records may be assigned. From about 250, Tiberius Coruncanius, originally from Tusculum, was the first plebeian to hold such a sacred position, ${ }^{49}$ he was possibly the first to be elected in the modified comitia tributa [...] Pomponius ${ }^{50}$ says he was the first who offered legal advice public. ${ }^{51}$

Hence, Rüpke claims that the commentarii pontificum were possibly created in $249 \mathrm{BC}$ by the first plebeian to become pontifex maximus, Tiberius Coruncanius. He argues that the process of literary development was slow and gradual, thus excluding an extensive "edition" of the existent written material. The author suggests that $249 \mathrm{BC}$ was the starting point for the written records of religious events and that Coruncanius instituted the continuous record of pontifical commentarii, whose purpose was not to write history, but to keep a written record of events in order to collect and document data and precedents on matters relating to law and rituals.

\footnotetext{
${ }^{48}$ More details in Ana Rodriguez-Mayorgas, "Annales Maximi: Writing, Memory and Religious Performance in the Roman Republic", In: André P.M.H. Lardinois; Josine H. Blok; Mark G.M. van der Poel (Ed.), Sacred Worlds: Orality, Literacy and Religion, Mnemosyne Suppl., 8, Leiden, Brill, 2011, p. 235-253, and Elizabeth Rawson, "Prodigy lists and the use of the Annales Maximi", Classical Quarterly, vol. 21, 1971, p. 158-69, 168-9.

${ }^{49}$ The lex Olgunia, dated from 300 a.C., allowed the commoners to take position as priests in the colleges of pontiffs and augurs.

${ }^{50}$ About Pomponius, see Dig. 1.2.2.35.

51 Jörg Rüpke, Fasti sacerdotum: A Prosopographic of Pagan, Jewish, and Christian Religious Officials in the City of Rome, 300 BC to AD 499, Oxford, New York, Oxford University Press, 2005, p. 31-2.
} 
The picture presented here of the commentarii of Coruncanius suggests two corollaries: while the beginning of regular records may be related to the onset of the new activities mentioned, we can assume that the accumulation of facts was also somewhat oriented to the past. [...] If Livy or Valerius Antias have had data that reached to $332 \mathrm{BC}$, this period of eighty years of the mark of $249 \mathrm{BC}$ corresponds to the horizon of three generations usually accessible to oral history. ${ }^{52}$

Rüpke also suggests that the tabulae pontificum and the commentarii pontificum were interrelated:

If this characterization is correct, the material cited [by ancient authors] of the libri or commentarii pontificum by antiquarians should be seen as belonging to the commentarii started by Coruncanius. [...] All the sources related to the "historiographical" activity of the pontiffs report that each year the pontifex maximus published a tabula dealbata listing the most important events. According to our reconstruction of the character of commentarii pontificum, this tabula may not have been a primary record, but extracts addressed to a wider audience. ${ }^{53}$

Regarding the content of the tabulae, the mention to the excerpt about eclipses and prices of grains in Cato suggests other interpretation: in the context of the $3^{\text {rd }}$ century BC, both of these events were calculated or foreseen by religious experts, so these announcements could avoid problems and could ensure social order. ${ }^{54}$ Rüpke also points out the difficulties of interpretations that put the prodigies as the leading purpose of the Annales Maximi: the record of prodigies was a duty of the magistrates, namely consuls and urban praetors, and that only prodigies that were recognized by these magistrates as being of public interest were forwarded to priests for their treatment. ${ }^{55}$

If the commentarii pontificum started with Coruncanius, the publication of the tabula was maintained until Mucius Scaevola, according to Cicero, and the compilation of the Annales maximi in 80 volumes has been associated to this rupture. If Mucius Scaevola had stopped the writing of the tabula, would he have stopped the commentarii also? Probably not. In the $1^{\text {st }}$ century BC, texts addressing the ritual rules were an important textual genre, and based on Macrobius (Sat.3.13.10-2), the commentarii by the pontifex maximus continued to be written and maintained.

\footnotetext{
52Jörg Rüpke, Fasti sacerdotum: A Prosopographic of Pagan, Jewish, and Christian Religious Officials in the City of Rome, 300 BC to AD 499, Oxford, New York, Oxford University Press, 2005, p. 33.

53/dem, Ibidem, p. 33.

${ }^{54} \mathrm{~J}$ rrg Rüpke uses Plutarco, Aem. 17, to support this interpretation, on ritual procedures for the eclipse announced before the battle of Pydna, in 168 BC, and Livius, 44.37.6, with his comment about the intention of the action: ne quis id pro portento acciperes.

55Jörg Rüpke, op cit., p. 34. See also S. Rasmussen, Public Portents in Republican Rome, Roma, L'Erma di Bretschneider, 2003, p. 35-52; for the proceedings of procuratio prodigiorum.
} 
In Rüpke's view, the idea of Mommsen that the Annales maximi had been compiled and published by Mucius Scaevola demands reconsideration. ${ }^{56}$ The question of how Scaevola have compiled in eighty volumes pontifical records of at least half a millennium of existence was one of the major elements of the criticism of the interpretation of Mommsen. But this is a minor problem, according to Rüpke, when we deal with the hypothesis that the records were initiated in $249 \mathrm{BC}$, thus comprehending a period shorter than 200 years. If we consider that ancient tabulae were preserved - although Rüpke found absurd the idea that they were stored in the residence of the pontifex maximus - there would be less than 200 tabulae to compile, without excluding the possibility of records dated before the $3^{\text {rd }}$ century BC. Rüpke argues that Scaevola was in a rather fragile political position back then, after the death of Tiberius Gracchus, whose reforms he supported. This could partly explain his compilations of the Roman legal system through which he became an undeniable reference figure for the Roman government elite.

\section{Roman religion is far less rigid and schematic than modern historians believe, and the links between innovation and conservatism also involved "intellectual" experts}

In short, Rüpke suggested that the commentarii existed for internal use in the college of pontiffs only, as well as the commentarii from other collegia. These were kept with the pontifex maximus, representing a dossier of great authority that could be used to construction of the past. Scaevola would have recognized the political potential of the commentarii pontificum and their summary the tabula dealbata, cited by ancient authors - and would have used them in the creation of an "apocryphal" literature - the Annales Maximi. The novelty of the publication of the Annales would have been hidden by the references to tabulae pontificum, and his books were then considered not an innovation, but a "new edition" of the ancient material, thus assuring their religious and consequently political authority. Therefore, the commentarii of the college of pontiffs were instituted in $249 \mathrm{BC}$ and, annually, a written excerpt would be put on a tabula and hung on the external walls of the pontifex maximus' residence. The Annales Maximi, on the other hand, would represent a published edition of the commentarii by Mucius Scaevola in Late Republic.

By way of conclusion, I believe that the rigorous and well documented interpretation by Rüpke on the Annales Maximi solves a series of problems and brings

56 Jörg Rüpke, Fasti sacerdotum: A prosopographic of Pagan, Jewish, and Christian religious officials in the city of Rome, 300 BC to AD 499, Oxford; New York, Oxford University Press, 2005, p. 35, contra Bruce Frier, Liber Annales Pontificium Maximorum: The Origins of the Annalist Tradition, Ann Arbor, University of Michigan Press, 1999, p. 193-200. 
a fresh meaning to these books so frequently cited in modern historiography. In any case - as the polemics remains, and questions are still more abundant than conclusions - it is important to note that Roman religious tradition in the Middle and Late Republic was only partly transmitted through written texts and kept in private documents such as those by the collegia, and they were not compiled and systematized in any corpus. John Scheid ${ }^{57}$ asserts that the attempts of reconstruction of the Roman religious literature in modernity have failed by two main reasons: incomprehension of the nature of Roman rituals and non-consideration of form and intention in priestly writings. According to the author, Roman religious tradition consisted of two main aspects: a) ritual calendar and precise instructions for practitioners (libelli e formulae), b) religious law. The responses by priests to requests were recorded not only in annual reports (commentarii), but also in Senate reports, specifically when they would become senatus consulta or edicts. Thus, priestly archives seem to have been accessible only to priests, and whoever wanted to (or could) consult the pontifical jurisprudence was supposed to carry out an extensive research in the archives of the Senate, for none of them would have been stored in specific books. Different collegia stored their commentarii with annual records, but these cannot be considered "sacred books".

Finally, we can see how incipient the current knowledge is about these questions. The ancient texts do not represent a definitive and undeniable corpus of concepts and definitions on which we can rely. As Scheid argued, ${ }^{58}$ Roman religion is far less rigid and schematic than modern historians believe, and the links between innovation and conservatism also involved "intellectual" experts of law and religion.

Religion is an important factor in the domain of public communication. In the case of Rome, their study allows us to observe a moment of consolidation of public space, and the texts of the priestly colleges were inserted in and nourished the Roman public life. The commentarii pontificum were established in this moment of organization and compilation of rules from the $3^{\text {rd }}$ century $\mathrm{BC}$ on, settled on the improvement of writing and systematization of practices and institution in laws, calendars and rules. Rüpke defined this process as an "instrumental rationalization" of ritual language aiming at possessing and using these elements ${ }^{59}$ and Mary Beard stressed the associations between religion and writing in terms of "religious codification" and "political competition", and thereby discusses the implications of writing in Rome and its impact

\footnotetext{
57John Scheid defends the oral character of Roman religious tradition and their rituals, which support it. He states the difficulties found in modernity as to rituals in the opposition of inner spirituality versus practice, for example, and as to priesthoods because of the erroneous belief that there was an innate religiosity stolen by priests and turned into a ritual system by means of their writings, cf. esp.: John Scheid, "Oral tradition and written tradition in the formation of sacred law in Rome," In: Clifford Ando; Jörg Rüpke (Ed.), Religion and Law in Classical and Christian Rome, Stuttgart, PawB 16, 2006, p. 16-19.

58/dem, Ibidem, p. 33.

${ }^{59} \mathrm{Jörg}$ Rüpke, Religion in Republican Rome: Rationalization and Ritual Change, Philadelphia, University of Pennsylvania Press, 2012.
} 
on religious systems for political life and social order..$^{60}$ The commentarii from both priestly colleges and magistrates are examples of the writing as a tool for social communication and control, and the Annales Maximi, compiled and published by Scaevola - if we assume the hypothesis by Rüpke - are an example of the union between writing and religion as a means of political competition. These texts were important media of communication between Roman nobiles among themselves, between them and the municipal elites and other groups that formed the populus in the urbs and the Imperium.

\footnotetext{
${ }^{60}$ Mary Beard, "Documenting Roman Religion," In: Claudia Moatti (Ed.), La mémoire perdue: recherches sur l'administration romaine. Coll. EFR-A, 243, Paris, École Française de Rome, 1998, p. 75-101; “Ancient literacy and the function of the written word in Roman religion," In: Mary Beard et al, Literacy in the Roman World, Journal of Roman Archaeology, Suppl. 3, 1991, p. 35-54; "Writing and Religion," In: Sarah I. Johnston, Ancient Religions, Cambridge-Mass, Harvard University Press, 2007, p. 127-138.
} 